\title{
Consumption and Use of Snail Limicolaria Flammea (Müller, 1774) in the City of Abidjan, Cote D'ivoire
}

\author{
Sea Tehi Bernard ${ }^{1, a}$, Envin Bogui Jacques Anicet ${ }^{1, \mathrm{~b}}$, Akoa Essoma Edwige Flore ${ }^{1, c, *}$, \\ Saki Suomion Justin ${ }^{1, d}$, Kouamé Lucien Patrice ${ }^{2, e}$, \\ ${ }^{1}$ Laboratory of Biotechnologies, Department of Biochemistry, UFR Biosciences, Félix Houphouët-Boigny University, 22 BP 582 Abidjan 22, \\ Côte d'Ivoire. \\ ${ }^{2}$ Laboratory of Biocatalysis and Bioprocesses, Department of food science and technology, Nangui-Abrogoua University, 02 BP 801 \\ Abidjan 02, Côte d'Ivoire \\ *Corresponding author

\begin{tabular}{|c|c|}
\hline A R T I C LE I NFO & A B S T R A C T \\
\hline $\begin{array}{l}\text { Keywords: } \\
\text { Limicolaria flammea } \\
\text { Consumption } \\
\text { Use of snail } \\
\text { Diseases treated } \\
\text { Ethnic groups }\end{array}$ & $\begin{array}{l}\text { The nutritional survey on the snail Limicolaria flammea (Müller, 1774) integrated several aspects } \\
\text { and made it possible to understand in particular socio-demographic characteristics of populations } \\
\text { surveyed, the knowledge of the snail Limicolaria flammea (according to municipalities visited), } \\
\text { vernacular names, consumption parameters, associated uses and the conservation of the meat of this } \\
\text { snail. It appears that } 55.33 \% \text { of respondents are women and } 44.67 \% \text { are men. The most important } \\
\text { age group is between } 20-34 \text { years old. In this age group, } 50.12 \% \text { of people say they consume the } \\
\text { snail Limicolaria flammea. Ethnic groups, Akan }(55.73 \%) \text {, Krou }(35.21 \%) \text {, Mande }(6.26 \%) \text {, and } \\
\text { foreigners }(2.8 \%) \text { are thus represented in this study and have expressed their opinions on the } \\
\text { knowledge and consumption of this animal species. Vernacular names ( } 23 \text { vernacular names) are } \\
\text { quite different from each other according to ethnic groups. Consumption parameters showed that the } \\
\text { flesh of snail is used for food (65.65\%). Also, the shell of snail is used for medical (29.25\%), and } \\
\text { aesthetic }(8.95 \%) \text {. Diseases treated are pain ( } 20.46 \%) \text { and rheumatism }(6.90 \%) \text {. Investigations have } \\
\text { shown that } 61.70 \% \text { of consumers keep the snail's flesh fresh, } 38.30 \% \text { of them smoked. The storage } \\
\text { time most observed by consumers }(65.40 \%) \text { is } 1 \text { to } 4 \text { days. }\end{array}$ \\
\hline
\end{tabular} \\ ic groups
}

\section{Introduction}

Snail meat is consumed by humans several years ago (Daguzan, 1983). The meat of giant snails is highly appreciated by all populations of the world, especially West Africans (Dafem et al., 2008). This appreciation of snails is generally associated with the quality and flavour of their flesh. Thus, the flesh of the giant snail contains more than $60 \%$ protein (Friday, 2014) and almost all the amino acids essential to human needs (Cobbinah et al., 2008). Snail meat is a good source of minerals, mainly iron, calcium, phosphorus and magnesium (Friday, 2014). Several industries (medicinal, traditional, cosmetic and aesthetic) use snails in many applications (Codjia and Noumonvi, 2002). Edible snails are an important part of traditional medicine. Indeed, the hemolymph is said to promote infant development and snail drooling is a beauty product used to fight wrinkles (Sodjinou, 2000). In the dietary and therapeutic fields, meat and shells are used for healing, coughing and pertussis in the food sector, snails of the genera Archachatina and Achatina are highly preferred by the populations who consume them in various forms (Otchoumou et al., 2011). This strong appreciation of this species largely eclipses the existence of other edible snail species, particularly the snail Limicolaria flammea (Müller, 1774). As such, although many studies provide scientific data on the breeding and nutritional value of the snail of the genus Achatina, very few of them provide scientific knowledge with a general overview of the consumption of the snail Limicolaria flammea (Müller, 1774), which is consumed by certain populations. To this end, the objective of this work is to contribute to the valorization of the snail Limicolaria flammea (Müller, 1774). More specifically, this involves conducting an ethno-chonchiliophagic survey that takes into account socio-demographic characteristics, state of knowledge, consumption, supply methods, fields of use and conservation methods of the snail Limicolaria flammea (Müller, 1774). 


\section{Material and Methods}

The investigation required a hermetically sealed jar in which the snail Limicolaria flammea (Müller, 1774) was placed and a survey sheet. The geographical area where survey data have collected concerned ten (10) municipalities in the city of Abidjan (5'18'34" north latitude and $4^{\circ} 00^{\prime} 45$ west longitude), in particular: Koumassi, Port-bouët, Treichville, Marcory, Plateau, Adjamé, Attécoubé, Cocody, Abobo and Yopougon. The data collect took place in two months from November to December 2017. The method adopted in this work was random sampling. The data collection was done by selfcounting (respondents completed the questionnaire themselves) and interview-assisted methods for each respondent. The consumer survey sheet used to conduct the survey is divided into six parts. The first part concerned the socio-demographic status of the persons surveyed. It presents the identity of the respondent (gender, age, ethnicity, education level). Then, the second part concerns the state of knowledge of the snail Limicolaria flammea (formal knowledge, vernacular name, availability on the markets, period of availability of the year, ubiquity of the species). The consumption of the snail Limicolaria flammea constituted the third part of the questionnaire. This included the period, condition, occasion, frequency of consumption of the snail Limicolaria flammea, as well as the preparations associated with this species. Then, the snail's supply method and areas of use were also questioned. Finally, the methods of conservation (duration, method and state of conservation) of the snail Limicolaria flammea were discussed. The collection of information consisted after the consent of the respondents to submit a form containing a series of closed (yes or no answers) or open questions (allowing the respondent the flexibility to translate his or her opinion). In each commune, 150 persons were interviewed mainly in areas of great meeting such as car and bus stations, markets, restaurants and around schools. The survey therefore mobilized a total of 1500 people whose age category ranged from teenagers (less than 20 years old), adults (20 to 34 years old and 35 to 49 years old) and seniors (50 and over). Respondents (both male and female) were interviewed in households, on the street, in high traffic areas, in public squares and in markets.

\section{Statistical Analysis}

For data processing, the various information's collected on the survey sheets were analysed using IBM SPSS software 20. The quantitative data were used to calculate the percentages of respondent. The Chi square test was used for qualitative data. Then, the Chi square test made it possible to determine the socio-demographic influence on the snail Limicolaria flammea' consumption.

\section{Results}

Socio demographic characteristics of survey population and consumption of snail Limicolaria flammea

The table 1 presents socio demographics characteristics in function of consumption of snail Limicolaria flammea. The survey population was composed by $55.33 \%$ of women and $44.67 \%$ of men. For the age, adults between 20 and 34 years of age presented the highest percentage $49.91 \%$, in opposition to person between 35 and 49 years old who just registered $40.66 \%$ of respondents. People between 50 years old and more and teenagers (less than 20 years old) represented $3.62 \%$ and $5.81 \%$ respectively. Concerning the ethnic group, Akan (55.73\%), Krou $(35.21 \%)$, and Mande $(6.26 \%)$ were represented; so were Foreigners $(2.80 \%)$. The whole population was composed of literate $(93.67 \%)$ and illiterate $(6.33 \%)$. For the literate group, $6.08 \%$ of the respondents are from primary school, while $55.26 \%$ from high school and the others $(32.33 \%)$ from higher degree.

About consumption of snail Limicolaria flammea, survey shows that $93.30 \%$ of respondents consume the snail Limicolaria flammea and $6.7 \%$ doesn't consume this snail. Thus, it has more women $(51.13 \%)$ who consume the snail Limicolaria flammea than men (42.17\%). In addition, $46.85 \%$ of consumers are adults between 20 and 34 years of age, compared with $35.71 \%$ of adults between 35 and 49 years old and $2.25 \%$ of adults between 50 years old and more. Regarding the level of education, the majority of literate $(73.16 \%)$ consume this snail.

Table 1. Socio demographic characteristics of consumers according to consumption of snail Limicolaria flammea

\begin{tabular}{|c|c|c|c|c|c|c|}
\hline & Variables & Consumers (\%) & No Consumers (\%) & Total & Chi square & Asymptotic meaning \\
\hline \multirow{2}{*}{ Gender } & $\mathrm{F}$ & 51.13 & 4.20 & 55.33 & \multirow{2}{*}{71.13} & \multirow{2}{*}{0.00} \\
\hline & M & 42.17 & 2.50 & 44.67 & & \\
\hline \multirow{4}{*}{ Age } & Less than 20 & 5.31 & 0.5 & 5.81 & \multirow{4}{*}{65.33} & \multirow{4}{*}{0.00} \\
\hline & $20-34$ & 46.85 & 3.06 & 49.91 & & \\
\hline & $35-49$ & 35.71 & 4.95 & 40.66 & & \\
\hline & 50 and more & 2.25 & 1.37 & 3.62 & & \\
\hline \multirow{4}{*}{ Education } & Illiterate & 4.10 & 2.23 & 6.33 & \multirow{4}{*}{110.15} & \multirow{4}{*}{0.00} \\
\hline & Primary school & 4.87 & 1.21 & 6.08 & & \\
\hline & High school & 42.73 & 12.53 & 55.26 & & \\
\hline & Higher degree & 28.4 & 3.93 & 32.33 & & \\
\hline \multirow{4}{*}{ Ethnic Group } & Akan & 51.63 & 4.10 & 55.73 & \multirow{4}{*}{380.38} & \multirow{4}{*}{0.00} \\
\hline & Mande & 4.16 & 2.10 & 6.26 & & \\
\hline & Krou & 28.62 & 6.59 & 35.21 & & \\
\hline & Foreigners & 0 & 2.80 & 2.8 & & \\
\hline
\end{tabular}

If asymptotic meaning $<0.05$, it means that there is a correlation between the variables 
Table 2. The consumption and non-consumption situation for each municipality of the snail Limicolaria flammea

\begin{tabular}{l|lrcrc}
\hline \multirow{2}{*}{$\begin{array}{c}\text { Municipalities } \\
\text { visited }\end{array}$} & \multicolumn{2}{c}{$\begin{array}{c}\text { Consumers of snail } \\
\text { Limicolaria flammea }\end{array}$} & \multicolumn{2}{c}{$\begin{array}{c}\text { No consumers of snail } \\
\text { Limicolaria flammea }\end{array}$} \\
\cline { 2 - 6 } & & Number & Rate $(\%)$ & Number & Rate $(\%)$ \\
\hline \multirow{5}{*}{ Northern Abidjan } & Abobo & 134 & 89.33 & 16 & 10.67 \\
& Adjamé & 47 & 31.33 & 103 & 68.67 \\
& Attékoubé & 63 & 42 & 87 & 58 \\
& Cocody & 114 & 76 & 36 & 24 \\
& Plateau & 65 & 43.33 & 85 & 56.67 \\
& Yopougon & 133 & 88.67 & 17 & 11.33 \\
\cline { 2 - 6 } South Abidjan & Sub-total & 556 & 61.77 & 344 & 38.23 \\
& Port-Bouët & 131 & 87.33 & 19 & 12.67 \\
& Koumassi & 8 & 5.33 & 142 & 94.67 \\
& Marcory & 139 & 92.67 & 85 & 7.33 \\
& Treichville & 65 & 43.33 & 257 & 56.67 \\
\cline { 2 - 6 } & Sub-total & 343 & 57.17 & 42.83 \\
\hline
\end{tabular}

Table 3 Vernacular names of the snail Limicolaria flammea

\begin{tabular}{|c|c|c|c|}
\hline Ethnic group & Ethnic & Vernacular names & Frequency $(\%)$ \\
\hline \multirow{9}{*}{ Akan } & Adjoukrou & Gba sèkrè & \multirow{9}{*}{5.33} \\
\hline & Alladjan & kpazin & \\
\hline & Avikam & Kôkônichè & \\
\hline & Aïsie & Likrèh & \\
\hline & Baoulé & Bouké kongo & \\
\hline & Agni & Kowgow & \\
\hline & Abbey & Roumon & \\
\hline & Ebrie & N'nohè & \\
\hline & Wan & Kogo & \\
\hline \multirow{6}{*}{ Krou } & Bete & Sioh & \multirow{6}{*}{35.21} \\
\hline & Yacouba & Drinh & \\
\hline & Webe & Sonsan & \\
\hline & Gagou & Bôbô & \\
\hline & Dida & Gnipisioh & \\
\hline & $\mathrm{Neo}$ & Srakiè & \\
\hline \multirow{4}{*}{ Mande } & Koulango & Dédésaki & \multirow{4}{*}{6.66} \\
\hline & Lobi & Méhé & \\
\hline & Gouro & Kéké & \\
\hline & Maouka & Kérékété, Kékété & \\
\hline \multirow{3}{*}{ Foreigners } & Malien & Kôtô & \multirow{3}{*}{2.8} \\
\hline & Guineen & Djambata tossokum & \\
\hline & Burkinabe & Garwewon & \\
\hline
\end{tabular}

For ethnic group, Akan are also the most consumer of this snail $(51.63 \%)$ compared by other ethnic group, followed by Krou (28.62\%). Statistical analysis (Chi square test) shows that socio-demographic parameters have an impact on the consumption of snail Limicolaria flammea. Indeed, gender, age, ethnic group and level of education of consumers influence the consumption of snail Limicolaria flammea in Abidjan city (Asymptotic meaning $=0.000<0.05$ ).

The consumption and non-consumption situation for each municipality of the snail Limicolaria flammea assessed in all 10 municipalities of the city of Abidjan gave a relatively different distribution depending on the municipality (Table 2). The snail Limicolaria flammea has a consumption rate of $61.77 \%$ in the municipalities located to the north of the city against a rate of $38.23 \%$ of people who don't know this species. In this respect, the municipalities of Abobo and Yopougon have a consumption rate of almost $90 \%$. Similarly, in the communes of the south of the city of Abidjan the distribution of this consumption rate shows that $57.17 \%$ of the people questioned consume the snail Limicolaria flammea against $42.83 \%$ of those who claim not to consume this snail. Also, the municipalities of Marcory and Port-Bouët have a consumption rate of $92.67 \%$ and $87.33 \%$ respectively.

\section{Vernacular names of the snail Limicolaria flammea}

The investigation revealed twenty three (23) vernacular names (local names) of the snail Limicolaria flammea (Table 3 ). The vernacular names of the snail are quite different from one ethnic group to another. To this end, a vernacular name of the snail Limicolaria flammea corresponds to each ethnic group. Thus, according to the interviewees, variations in the phonetics of the vernacular names of the snail Limicolaria flammea were found. But this variation is less noticeable when it comes to the same ethnic group. 


\section{Consumption parameters}

The survey showed that $78.14 \%$ of the people questioned the snail is consumed in cooked form (Figure 1). Also, according to $13.56 \%$ and $8.30 \%$ of the surveyed consumers consume the snail in the fried form and in powder form respectively. Concerning the sources of supply of the snail Limicolaria flammea, consumers procure this snail by picking (by $67.29 \%$ of consumers), purchase (by $14.33 \%$ of consumers) and breeding (by $18.38 \%$ of consumers). For field of applied, respondants use the snail Limicolaria flammea in food (by $65.65 \%$ of consumers), medicine (by $26.30 \%$ of consumers) and aesthetics (by $8.05 \%$ of consumers).

\section{Use of different parts of snail Limicolaria flammea}

The results of the survey revealed that flesh and shells of snail Limicolaria flammea are used in three areas: food, medical and aesthetic (Figure 2). The snail flesh is used by $65.65 \%$ of respondants for food and $4.84 \%$ of consumers use in medicine (Figure 2A). However, the snail shell is used by $29.25 \%$ of consumers for medicinal and only $8.95 \%$ use snail shell for aesthetic (Figure 2B).

The diseases treated by snail Limicolaria flammea are pains (20.46\% of respondants) and rheumatism (6.90\% of respondants) (Figure 3).

Conservation of snail Limicolaria flammea flesh

The investigation showed that the snail Limicolaria flammea flesh is kept fresh or drying by smoke (Figure 4A). Indeed, $61.70 \%$ of consumers keep snail flesh fresh and $38.30 \%$ of them keep snail flesh smoked. The shelf life of Limicolaria flammea snail flesh is 1 to 4 days for $65.40 \%$ of consumers, 5 to 8 days for $22.67 \%$ of them and 8 to 15 days for $11.93 \%$ to others (Figure 4B). Concerning conservation methods, it is clear from survey that $14.32 \%$ of consumers conserve the snail Limicolaria flammea flesh by immersion in water and $31.46 \%$ of them by drying and $54.22 \%$ of consumers by refrigeration (Figure 4C).

\section{Discussion}

Results of survey indicate that the snail Limicolaria flammea is known and consumed by the majority of Ivorian populations. This situation could be explained by the fact that the snail Limicolaria flammea would integrate culinary cultural heritage of some populations, particularly those of Akan group and populations in forest areas (EDSCI-II, 2001). Similarly, the ubiquitous nature of this snail makes it an almost domestic species, hence the name garden snail, in the same way as the Archatina Achatina snail (Otchoumou et al., 2011). However, some of this population doesn't know the snail Limicolaria flammea. This observation could be explained by the fact that these people reside in municipalities with a level of urbanization that excludes the sustainability of green spaces and also that a part of this population interviewed is from regions in northern Côte d'Ivoire (Ekoue and Kuevi-Akue, 2002). From one ethnic group to another, vernacular names recorded during the survey revealed several equally different names. However, within the same group, the snail Limicolaria flammea keeps almost same phonetics in its name. In addition, the common theme used to designate and facilitate trade in the snail Limicolaria flammea is "small, small snail". This situation could be explained by the fact that there are several ethnic groups with several subgroups in Côte d' Ivoire. It could also be explained by the absence of a national language that would allow the snail Limicolaria flammea to be named in an acceptable way (EDSCI-II, 2001).

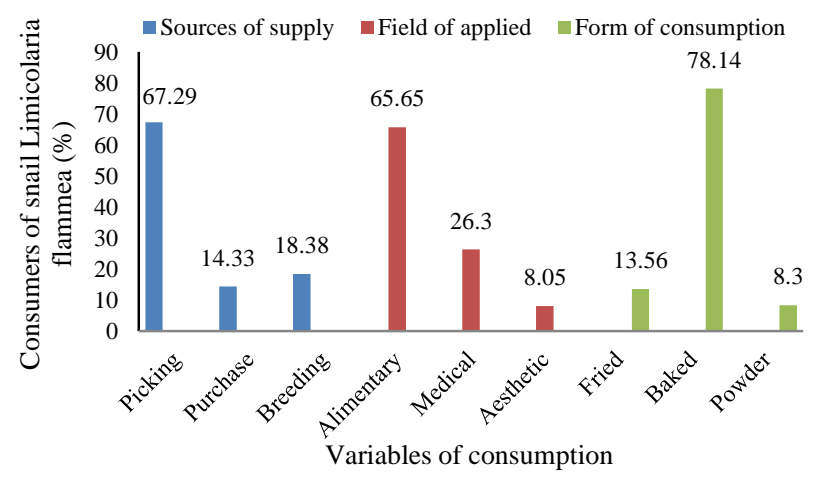

Figure 1 Sources of supply, field of applied and form of consumption of snail Limicolaria flammea
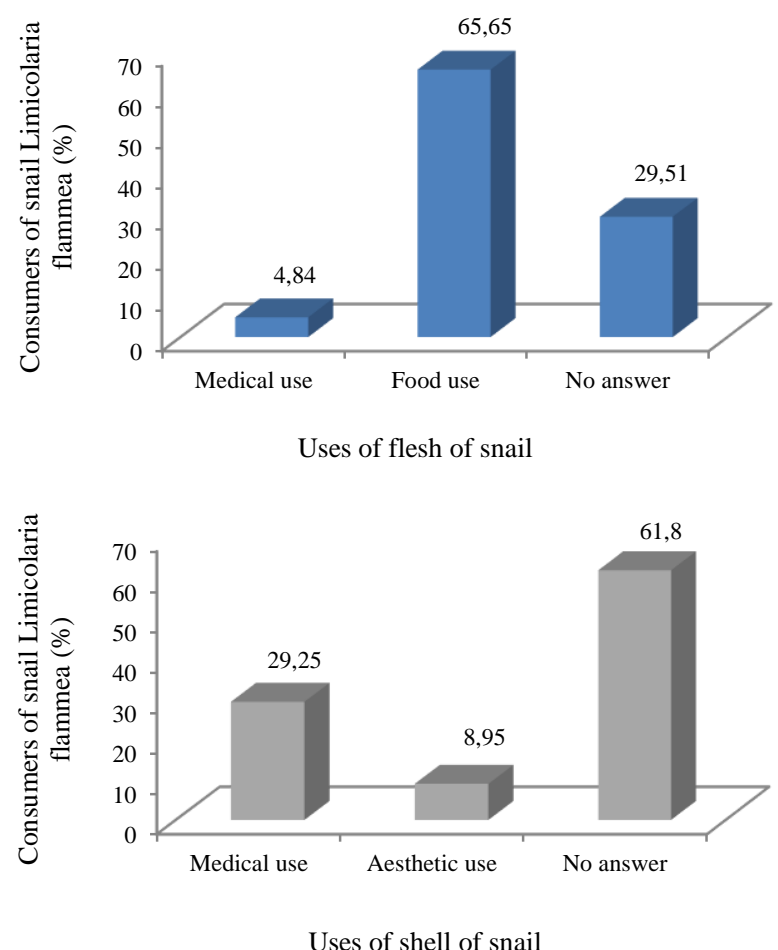

Figure 2 Use of differents parts of snail Limicolaria flammea according of consumers

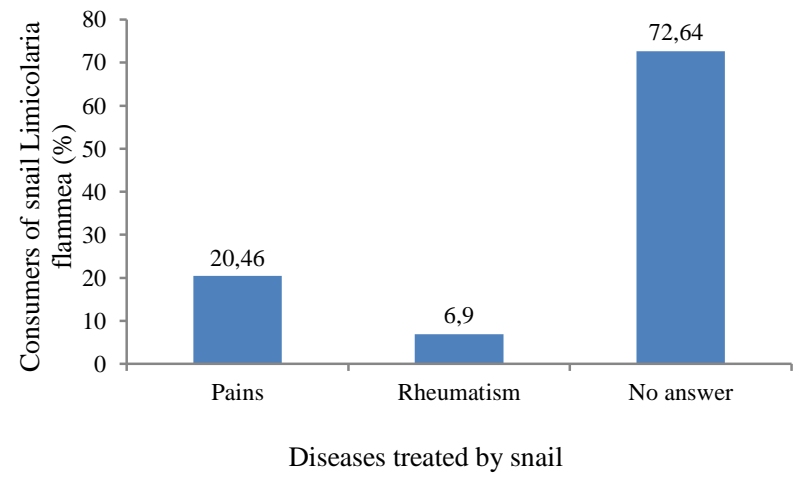

Figure 3 Diseases treated by snail Limicolaria flammea according of consumers 
Methods of obtaining the snail Limicolaria flammea from populations are of three kinds: collection from gardens or fields, purchase in markets of various municipalities visited and breeding in open enclosures. The collection is the most frequent and simple way to obtain snails Limicolaria flammea. This would be explained by the fact that the snail Limicolaria flammea would be harmless, ubiquitous and very slow to move. The snail's slowness would significantly reduce its ability to spread in the wild and escape its potential predators during its movement (Bonte et al., 2012). The purchase is the second method of obtaining these snails by the populations. In periods of abundance, surplus snails collected are transported to various markets for sale (Cobbinah et al., 2008). This method of obtaining it is still available. On the other hand, the breeding of the snail Limicolaria flammea is the most expensive and complicated method of production to implement because of technical and professional requirements that the breeding involves (Cobbinah et al., 2008). Several forms of consumption of the snail Limicolaria flammea were identified during the survey. The snail Limicolaria flammea can be eaten in cooked, fried or smoked form. Indeed, the smoked snail is not widely consumed by Ivorian population, because the size of the flesh of the snail Limicolaria flammea would be reduced further during the smoking of the snail and would make it difficult to recover the flesh for consumption. In addition, in urban areas it is difficult to cook with wood because of the development and use of domestic gas for different preparations. However, populations prefer cooking in sauce or frying the snail Limicolaria flammea. Cooking the snail Limicolaria flammea in sauce is the most popular form because it would be quick and easy to use. The conservation over time of the snail Limicolaria flammea according to the survey is done in two states. These are fresh and smoked. The conservation of the smoked snail is not recommended because the flesh of the snail can be contaminated with molecules highly toxic (PAHs) to the body as a result of the combustion of wood (Stolyhwo and Sikorski, 2005). The shelf life of the snail Limicolaria flammea is one to four days. This situation could be explained by the fact that populations that consume the snail do so in response to an immediate desire or in order to compensate for the lack of a protein source during lean season (Onzo et al., 2014). The survey revealed that the fields of use or applications of the snail Limicolaria flammea concern food, medicinal and aesthetic fields. The food sector is the one with the most applications. Food consumption of snail meat is more popular because of its many biochemical and nutritional potential (Kouadio et al., 2015). The snail meat Limicolaria flammea contains $46.65 \%$ of proteins essential for strengthening nutritional status of malnourished people (Envin et al., 2018). Also, the nutritional value of the flesh of the snail Limicolaria flammea is reflected in its high content of mineral elements, particularly calcium and phosphorus, which are important for strengthening body bone mass and for tooth formation (Okon et al., 2016). Medicinal value of the snail Limicolaria flammea would be reflected in the use of the flesh and shell. To this end, the shell of this snail would be transformed into powder to which would be added to ointment (shea butter) to provide massage and fight against pains (Ekoué and Kuevi-Akue, 2002). In the aesthetic field, the snail shell is the most commonly used. Indeed, the snail shell Limicolaria flammea can contribute to decoration of several supports including cars in wedding ceremonies. The size of the shell of this snail would be an advantage in handling because shell participates in ornament and adornment of young ladies who have recently given birth (Bouye et al., 2017).
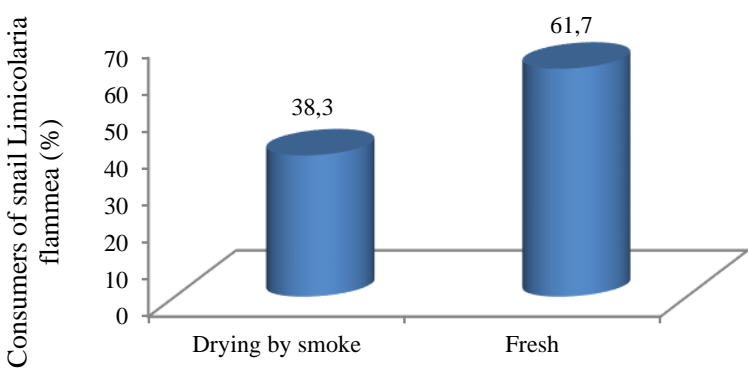

Conservation form

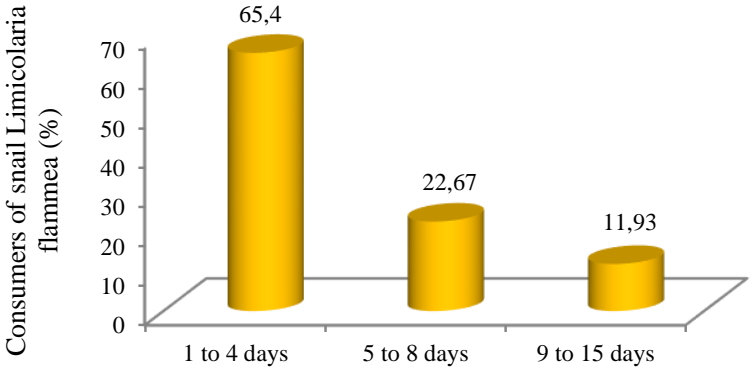

Snail shelf life

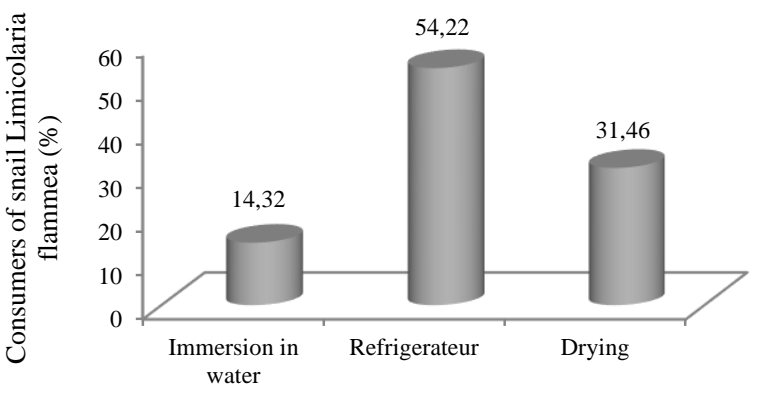

Storage method

Figure 4 Conservation methods and duration of snail Limicolaria flammea according of consumers

\section{Conclusion}

The snail Limicolaria flammea like other snail species is a meat very well known and consumed by the Ivorian population as well as populations of the sub-region living in this country. Vernacular names of the snail Limicolaria flammea differ from one ethnic group to another. Sources of supply of populations in this snail are the gathering in humid zones, purchase in markets and breeding. The snail Limicolaria flammea is consumed in fried form, cooked in sauce and smoked by the Ivorians. Most used methods of conservation are the conservation by drying by smoke and the conservation in the shell fresh state. The shelf life of the snail fresh is 1 to 4 days. 


\section{References}

Bouye TR, Ocho-Anin A, A Louise, Karamoko M, Otchoumou A.2017.Étude de la croissance d'un escargot géant africain comestible: Achatina achatina (Linné, 1758), élevé sur du substrat amendé à la poudre de coquilles d'escargot. J. Appli. Biosci. 109: 10630-10639. DOI: 10.4314/jab.v109i1.7.

Bonte D, Van Dyck H, Bullock JM, Coulon A, Delgado M, Gibbs M, Lehouck V, Matthysen E, Mustin K, Saastamoinen M, Schtickzelle N, Stevens VM, Vandewoestijne S, Bagu\&te M, Bartoń K, Benton TG, ChaputBardy A, Clobert J, Dytham C, Hovestadt T, Meier CM, Palmer SCF, Turlure C, Travis JMJ. 2012, Biol Rev Camb Philos Soc, 87: 290-312.

Cobbinah JR, Vink A, Onwuka B. 2008. Snail farming: production, processing and marketing. Agrodok 47, Agromisa Foundation, Wageningen, the Netherlands. DOI:10.4102/sajhrm.v16i0.1025. ISBN Agromisa: 978-908573-108-5 ISBN CTA: 978-92-9081-398-9.

Codjia JTC, Noumonvi RCG. 2002. Les escargots géants. Guide technique d'élevage, 2, 36p.

Dafem R, Ngoula F, Teguia A, Kenfack A, Tchoumboue J. 2008. Performances de reproduction de l'escargot géant africain Archachatina marginata en captivité au Cameroun.Tropicultura, 26,3: 155-158. ISSN 0771-3312.

Daguzan J. 1983. L'élevage de l'escargot ou apiculture. Rennes France. pp. 65-114. DOI: 1051 /animres: 19820402.

EDSCI-II. 2001. Deuxième enquête démographique et santé en Côte d'Ivoire 1998-1999. Rapport, (2): 26-28. https: //dhsprogram.com/pubs/pdf/PR21/pr21

Ekoue SK, Kuevi-Akue K. 2002. Enquête sur la consommation, la repartition et l'élevage des escargots géants au Togo. Tropicultura, 20: 1, 17-22. ISSN 0771-3312.

Envin BJA, Ekissi GSE, Sea BT, Kouame PL. 2018. Biochemical and nutritional composition of garden snail (Limicolaria flammea) fleshconsumed in Côte d'Ivoire. J. basic appl. Res 4(4): 63-70. ISSN 2413-7014.
Friday EU, Williams ON, Essien C. 2014. Effect of processing on the proximate and Mineral Composition of Archachatina marginata and Achatina achatina. Food and Public Health, 4(1): 10-14. e-ISSN: 2162-8440, p-ISSN :2162-9412.

Kouadio EJP, Konan KH, Brou K, Dabonné S, Dué AE, Kouamé LP. 2015. Etude de quelques paramètres de croissances et de valeur nutritive des variétés d'escargot Archachatina marginata (saison) élevées en milieu naturel. Tropicultura, 33 (1): 38-45. ISSN 0771-3312, e-ISSN 2295-8010.

Okon B, Ibom LA, Ina-Ibor OB, Owai PU. 2016. Nutritional evaluation of African land snail (Archachatina marginata saturalis) fed diet containing full fat rubber as a replacement for soybean. NJAFE 12(2): 1-8.https:// doi.org/10.5897 /ajar12.1937.

Onzo FC, Aka S, Azokpota P, Dje KM, Bonfoh B. 2014. Cartographie des espèces de feuilles végétales utilisées comme emballages alimentaires en Côte d'Ivoire. J. Rech. Sci. Univ. Lomé (Togo). 2014. Série A, 16(2): 19-36. https:// doi.org//10.1172/JC/72181.

Otchoumou A, Duppont-Nivet M, Dosso H. 2011.Effects of diet quality and diatery calcium on reproductive performance in Archachatina ventricosa (Gould, 1850), Achatinidae under indoor reaning conditions. INVERTEBR. REPROD. DEV./ ISSN 0792- 259 print /ISSN 2157-0272.http: //www.tandfonline.com/loi/tinv20.

Sodjinou EG. 2003.Commercialisation des escargots géants africains (Achatines) dans les Départements de l'Atlantique et $d u$ Littoral au Sud-Béninin. Annales des Sciences Agronomiques du Bénin. Volume 4(2): 161-187. http://dx.doi.org/10.4314/asab.v4i2.43374

Stolyhwo A, Sikorski ZE. 2005. Polycyclic aromatic hydrocarbons in smoked fish. Crit. rev. Food Chem., 91 (2): p. 303-311. ISSN 0308-8146. 